\title{
Characteristics of The Company and Tax Avoidance Manufacturing Company in Food and Beverage Industry Sector Listed in Indonesia Stock Exchange Period 2012-2016
}

\author{
M. Zikrullah ${ }^{1}$, Martini \\ \{zikrullahmuhamad77@gmail.com ${ }^{1}$, martini@budiluhur.ac.id² $\}$ \\ Economic and Business Faculty, Universitas Budi Luhur, Jakarta, Indonesia ${ }^{1,2}$
}

\begin{abstract}
Tax evasion is to avoid taxes by exploiting loopholes contained in legal tax laws. This study aims to examine the effect of the characteristics of the company proxied by profitability, leverage, size, capital intensity, and inventory intensity against tax avoidance in manufacturing companies of food and beverage industry sector listed in Indonesia Stock Exchange period 2012-2016. The sample of this research consists of 11 manufacturing companies of food and beverage industry sector listed in BEI period 2012-2016 by using sampling method of purposive sampling. The analysis technique used in this research is multiple linear regression analysis. The result of the analysis shows that the variab characteristics of the company proxied by profitability, capital intensity, inventory intensity have a significant effect on tax avoidance, no significant effect on tax avoidance. While the variable characteristics of the company in proxies by size and leverage have no effect on tax avoidance.
\end{abstract}

Keywords: Profitability, leverage, size, capital intensity, inventory intensity and tax evasion

\section{Introduction}

Tax is the pulse of a country's development. National development requires a lot of funds. Therefore, the government through the Directorate General of Taxes (DGT) seeks to increase state revenues in the tax sector. According to data from the Central Bureau of Statistics (BPS), almost $70 \%$ of revenues from the State Budget (APBN) comes from tax revenues. For the state, taxes are an important revenue source that will be used to finance state expenditures, both routine expenditures and development expenditures. Conversely, for the company, the tax is a burden that will reduce the profit before tax. Thus, companies often attempt to make the minimum tax payment possible.

Events related to tax evasion can be seen from the case of Panama Papers which reveal the dark practices of thousands of stealth companies and the behavior of thousands of super-rich people around the world in their financial management. Panama Papers also reveals how the rich people are trying to avoid taxes by saving money or doing business abroad. Panama is only one of dozens of tax haven states that provide facilities for corporations, super-rich people and other criminals to avoid and evade taxes [1]. 
Panama Papers shows that the potential for tax revenues of Indonesia is evaporating very large amounts. This shows that the world including Indonesia is already in an era of tax evasion. This should be a momentum for the Government of Indonesia to immediately eradicate the practice of tax evasion, tax evasion and money laundering practices by Indonesian taxpayers, both individuals and legal entities.

Panama Papers also shows the poor financial system and global economy. Economic system, must be done rearrangement. Indonesia needs to pioneer changes in global financial governance related to taxation system, cessation of taxation and banking data confidentiality regime, exchange of interstate information and strengthening of law, administration and institutional taxation.

The potential tax evaporated from Indonesia due to the practice of illegal money laundering each year is predicted by Global Financial Integrity (GFI) of almost IDR 200 trillion each year. The high rate of illegal money flow from Indonesia is due to the low level of taxpayer compliance (rich, super rich, and corporate), the high prevalence of tax corruption, the practice of embezzlement and tax evasion by complicated methods of financial finance, the low performance of Indonesian tax authorities. Publish What You Pay Coalition (PWYP) states that Indonesia is in the 7th position of countries from countries that have the highest flow of money forbidden. In the period of 2003-2012, Indonesia failed to deliver Rp 187,844 million (IDR 1,699 trillion with an average exchange rate of IDR 9,000 / USD) or an average of USD 18.7784 million (IDR 167 trillion per year). With the same method of calculation, PWYP Indonesia records the total estimated flow of illicit money in Indonesia in 2014 of IDR. 2.277 trillionor equivalent to $11.7 \%$ of the total APBN-P Year 2014.

In response to the emergency issue of this tax crime, the Just Tax Forum asks the government to also cancel the plan of giving tax amnesty to the super taxpayer because it will be counter-productive to the effort of optimizing tax revenue. It will also be a step back in taxation-money laundering law enforcement. In addition, tax forgiveness will lower the level of taxpayer compliance to pay taxes, tax forgiveness will weaken the government's' prestige in the presence of super-rich and corporate and tax pardons will hurt the small-to-medium taxpayers (salariat, monthly wage) during this obedient tax pay. This is discussed in the Fair Tax Forum. The Fair Tax Forum comprises a number of institutions, including Perkumpulan Prakarsa, Seknas PWYP Indonesia, International NGO for Indonesia Development (INFID), Transparency International Indonesia (TII), ASPPUK, The Habibie Center, ICW (Indonesia Corruption Watch), IGJ (Indonesian for Global Justice), IHCS (Indonesian Human Rights Committee for Social Justice), ILR (Indonesian Legal Roundtable), P3M (Association of Pesantren and Community Development), YAPPIKA and YLKI (Indonesian Consumer Service Foundation).

According to the above description, Panama Papers should be a momentum for the Government of Indonesia to immediately eradicate the practice of tax evasion, tax evasion, and money laundering by Indonesian taxpayers, both individuals and legal entities.

In tax avoidance practice, the taxpayer does not clearly violate the law or interpret the law but is inconsistent with the intent and purpose of the law. Tax avoidance practices undertaken by the management of a company solely.

\subsection{Research Purposes}

The purpose of this study to know empirically to analyze the influence of company characteristics with proxy profitability, leverage, size, capital intensity, and inventory intensity against tax avoidance). 


\section{Literature Review}

\subsection{Tax Avoidance}

According (Nurfadilah et al., 2015), tax avoidance is an arrangement to minimize or eliminate the tax burden by considering the resulting taxes [2]. According to Suandy (2013), tax avoidance is a legal tax-deductible undertaking by utilizing provisions in the field of taxation optimally, such as exceptions and deductions that are permitted as well as the benefits of unregulated matters and weaknesses is in the applicable tax laws. Tax avoidance can be measured by Effective Tax Rate (ETR) [3]. One way to measure how well a company manages its taxes is by looking at its effective rates. Tax evasion in this study was measured using Effective Tax Rate (ETR) by calculating the income tax expense paid divided by commercial profit before tax [3]. The greater the value of ETR then the lower the rate of tax evasion of a company.

\subsection{Company Characteristics}

Company characteristic is a characteristic or attribute attached to an entity [4]. The characteristics of the company can be seen from various aspects, including the profitability of the company, the level of liquidity, financial leverage, share ownership, firm size, type of business or industry and others, Zadeh and Eskandari, (2012) in (Mulyani, Darminto and N.P, 2014) [5]. In this study the characteristics of companies used through proxy profitability, leverage, size, capital intensity, and inventory intensity.

\subsection{Profitability}

Profitability is the ability of a company to earn profit (profit) in a certain period. According (Fahmi, 2013), profitability is a ratio that measures the effectiveness of management as a whole indicated by the size of the level of profit gained in relation to sales and investment. The better the profitability ratio, the better the ability to capture the high profits of the company. An approach that can reflect the company's profitability is return on assets (ROA) [6].

\subsection{Leverage}

Leverage or solvency is a measure of how much assets owned by the company is financed by debt [7]. According to(Ariawan and Setiawan, 2017), Leverage is a ratio that shows the amount of debt owned by the company or the level of debt used by the company to finance its operating activities [8]. In this research, leverage ratio is measured using Debt to Total Asset Ratio (DAR). Debt to Total Asset Ratio (DAR) is one of the ratios used to measure the amount of company assets in which the ratio is used to measure how much the company's assets are financed by total debt [7].

\subsection{Size of Company}

Company size as a scale or value that can classify a company into categories large or small based on total assets, log size, and so on. The larger the size of the company, the transactions will be more complex, Respect and Marfua'ah [9]. Large firms have greater access and wider 
access to external sources of funding, so getting a loan will be easier because large firms have a greater chance of winning the competition or staying in the industry [10]. The size of the company is measured based on the total assets owned by the company. this consideration is because the total assets of the company is relatively more stable than the amount of sales and market capitalization value.

\subsection{Capital Intensity}

Capital intensity describes how much of a company's wealth is invested in fixed assets. The intensity of ownership of a fixed asset may affect the company's tax expense due to depreciation expense attached to fixed assets. Depreciation expense incurred on the ownership of a fixed asset will affect the company's taxes, it is because depreciation expense is one of the burdens that reduce taxes Blocher, 2007 [11]. Capital intensity ratio is an investment activity conducted by a company related to investment in the form of fixed assets (capital intensity) and inventory (inventory intensity). The ratio of capital intensity can show the level of efficiency of the company in using its assets to generate sales [12].

\subsection{Inventory Intensity}

Inventory intensity is one of the components of assets that is measured by comparing the total inventory with total assets owned by the company, [9]. The higher the inventory intensity, the more effective and efficient the company will be in managing its inventory. The Inventory Intensity Ratio shows the effectiveness and efficiency of a company to manage its investment in inventories reflected in the number of times that inventory is played during a given period [13]. If the inventory intensity of firms is high then the level of costs will decrease and increase the amount of profit, the higher the inventory intensity will increase the level of corporate tax aggressiveness [11].

\subsection{Framework}

This research focuses on veriabel which is expected to influence tax avoidance that is influence of company characteristic which proxied by profitability, leverage, size, capital intensity and inventory intensity at manufacturing company sub sector of consumption industry listed on BEI in 2014- 2016. Here is a picture of the theoretical framework developed by researchers as follows: 




Fig. 1. Theoretical framework.

\subsection{Research Hypothesis}

Based on the indication of the problem, the foundation of the theory and previous research, the proposed hypothesis is as follows:

Profitability is one measure for the performance of a company. Profitability of a company shows the ability to generate profit in certain period at a certain level of sales, assets and capital stock. Profitability consists of several ratios, one of which is return on assets (ROA). Return on assets serves to measure the effectiveness of the company in the use of its resources, Siahaan (2004), in [7]. This ratio is most often highlighted in the analysis of financial statements because it can show the success of a company in generating profits within a certain period. The higher the ROA, the greater the profit earned by the company. Related research conducted by Darmawan (2014) and Dewinta and Setiawan (2016) that the ROA has a positive effect on tax avoidance [14], [7]. Based on the description, the hypothesis in this study are as follows:

\section{H1:Company Characteristics Proxy Profitability has an effect on tax avoidance.}

Leverage is a ratio to measure the extent to which firms use debt to finance investments. Leverage is measured by using the ratio of debt to equity ratio (DER). Debt toi equity ratio (DER) is the ratio of total debt to total equity of the company as a source of funding, [7]. It can be concluded that the higher the value of the leverage ratio, the higher the amount of debt funding from third parties used by the company and the higher the interest cost arising from the debt. In this case, high interest costs will give effect to the reduction of corporate tax. Related research conducted by(Koming Ayu Praditasari and Ery Setiawan, 2017) and (Ariawan and Setiawan, 2017) which in his research showed that leverage has a positive effect 
on tax avoidance [15],[8]. Based on the description in the above, the hypothesis used in this study are:

\section{H2: Characteristics of Proxy Leverage companies influence tax avoidance.}

Large companies are better able to use their resources to make better tax planning. However, the company can not always use its power to perform better tax planning because of the limits of the possibility of being the spotlight and the target of the regulatory decision - political cost theory [16]. Company size is a classification of a company based on the amount of assets it has. Large companies are also considered mature and relatively easier to gain access to capital markets [17]. Then it can be concluded the greater the asset the greater the size of the company. Siregar and Widyawati (2016) conducted a study related to the influence of corporate characteristics against tax evasion [9]. The results show that firm size has a positive effect on tax avoidance rate. Based on the description, the hypothesis used in this study are as follows:

\section{H3: Company Characteristics Proxy Size has an effect on tax evasion.}

Capital intensity is the ratio between fixed assets such as equipment, machinery and property to total assets, which represents the size of the company's assets invested in fixed assets required by the company to operate as indicated in percentages, [12]. In research conducted by Dewinta and Setiawan (2016) that capital intensity have a positive effect on tax avoidance [7]. Based on the research, the hypothesis used in this research is:

H4: Company Characteristics Proxy Capital Intensity has an effect on tax evasion.

Understanding of inventory intensity ratio is the effectiveness and efficiency of a company to manage its investment in inventory reflected in several times that inventory is played during a certain period (Etty and Rasita, 2005 in [9]. Inventory intensity ratio is one part of the asset that is proxied by comparing the total inventory with the total assets owned by the firm. Companies that invest in inventory in warehouses will cause the establishment of maintenance and storage costs of the inventory resulting in the company's total expenses will increase so it will be able to reduce the company's profit [12]. The results of research conducted by (Nugroho, Ahmar and Darmansyah, 2016), inventory intensity has a significant effect on tax avoidance (Tax Avoidance) Based on the result of the research, the hypothesis for this research is [11]:

H5: Characteristics of Proxy Inventory intensity companies have an effect on tax.

\section{Research Method}

\subsection{Data collection technique}

This study uses secondary data collected by writer that is in the form of financial statement data of manufacturing company of industrial sector of consumer goods listed in Indonesia Stock Exchange (BEI) year 2014 until period of year 2016, which have complete data in that period and published in website Bursa Efek Indonesia with the website http://www.idx.co.id/.

\subsection{Population and Sample Research}

The population in this research is manufacturing company of industrial sector of consumer goods listed in Indonesia Stock Exchange (BEI) from 2014 until 2016, which the data can be 
measured through the characteristic of companies that proxies through profitability, leverage, size, capital intensity and inventory intensity.

The sample in this research use Purposive Sampling technique. The criteria in the selection of this study sample, as follows:

1. Manufacturing Companies of the Consumer Goods Sector Industry listed on the Indonesia Stock Exchange (BEI) during the observation period, ie 2014-2016.

2. Manufacturing Company in the Consumer Goods Industry Sector which suffered losses in 2014-2016 has no tax burden.

3. Companies with incomplete financial statements.

\subsection{Research model}

The method of research in this study the authors use multiple linear regression because the authors analyze the influence of some independent variables on one dependent variable. The structural equation for the multiple linear regression analysis model is:

$$
\mathrm{Y}=\alpha+\beta 1 \mathrm{X} 1+\beta 2 \mathrm{X} 2+\beta 3 \mathrm{X} 3+\beta 4 \mathrm{X} 4+\beta 5 \mathrm{X} 5+\varepsilon
$$



\subsection{Operational Research Variables}

This study uses five independent variables, namely Profitability, Leverage, Size, Capital Intensity, Inventory Intensity and one dependent variable is tax avoidance (Tax Avoidance). The variables are as follow:

Table 1. Operasional Variable.

\begin{tabular}{lcccc}
\hline \multicolumn{1}{c}{ Variable } & Indicator & Scale & Data Source \\
\hline $\begin{array}{l}\text { Tax Avoidance (Y) } \\
\text { (Nugroho, Ahmar and Darmansyah, }\end{array}$ & ETR & Rasio & Financial statements \\
2016) & & & & \\
\end{tabular}




\begin{tabular}{|c|c|c|c|}
\hline $\begin{array}{l}\text { Profitability }\left(X_{1}\right) \\
\text { (Ariawan and Setiawan, 2017) }\end{array}$ & $\begin{array}{l}\text { ROA } \\
=\frac{\text { Net Income After Tax }}{\text { Total Assets }}\end{array}$ & Rasio & Financial statements \\
\hline $\begin{array}{l}\text { Leverage }\left(X_{2}\right) \\
\text { (Dewinta and Setiawan, 2016) }\end{array}$ & $\begin{aligned} D A R & \\
= & \frac{\text { Total liabilities }}{\text { Total Assets }}\end{aligned}$ & Rasio & Financial statements \\
\hline $\begin{array}{l}\text { Size }\left(X_{3}\right) \\
\text { (Christina Widhya Utami, 2013) [18] }\end{array}$ & $\begin{array}{l}\mathrm{SZE} \\
\quad=\mathrm{LN}(\text { Total Assets })\end{array}$ & Rasio & Financial statements \\
\hline $\begin{array}{l}\text { Capital Intensity }\left(\mathrm{X}_{4}\right) \\
\text { (Darmawan, 2014) }\end{array}$ & $\begin{array}{l}\text { CAP } \\
=\frac{\text { Total net Fixed Assets }}{\text { Total Assets }}\end{array}$ & Rasio & Financial statements \\
\hline $\begin{array}{l}\text { Inventory Intensity }\left(X_{5}\right) \\
\text { (Andini dan Sukartha, 2017) }\end{array}$ & $\begin{array}{c}I N V= \\
\frac{\text { Total Inventory }}{\text { Total Assets }}\end{array}$ & Rasio & Financial statements \\
\hline
\end{tabular}

\subsection{Classic Assumption Test}

\subsubsection{Normality test}

The following results of the normality test using the Kolmogorov-Smirnov Test One-Sample test.

Table 2. One-Sample Kolmogorov-Smirnov Test.

\begin{tabular}{lll}
\hline & & $\begin{array}{l}\text { Unstandardized } \\
\text { Residual }\end{array}$ \\
\hline $\mathrm{N}$ & Mean & 55 \\
Normal Parameters & aE- & \\
& Std. Deviation &, 03411472 \\
& $\begin{array}{l}\text { Absolute } \\
\text { Positive }\end{array}$ &, 060 \\
Most Extreme Differences & Negative &, 060 \\
Kolmogorov-Smirnov Z & &,- 043 \\
Asymp. Sig. (2-tailed) & &, 443 \\
& &, 989 \\
\hline
\end{tabular}
a. Test distribution is Normal
b. Calculated from data

Based on the One Sample Kolmogorov-Smirnov table seen on Asymp. Sig. (2-tailed) of 0.989. The significance value greater than 0.05 indicates that the data is normally distributed and this data is feasible for research. 


\subsubsection{Multicollinearity Test}

The following results are presented Multicollinearity test.

Table 3. Coefficients ${ }^{\mathrm{a}}$

\begin{tabular}{lll}
\hline Model & \multicolumn{2}{l}{ Collinearity } \\
& Tolatistics \\
Constant & & VIF \\
ROA &, 320 & 3,123 \\
LEV &, 384 & 2,605 \\
SZE &, 422 & 2,368 \\
CAP &, 286 & 3,492 \\
INV &, 315 & 3,172 \\
\hline
\end{tabular}

a. Dependent Variabel: ETR

From the results of multicolinearity testing in table 4.9 above, can be seen the value of VIF and Tolerance in the regression model in the test. It can be seen that the Company Characteristic variables consisting of ROA, LEV, SZE, CAP, INV proxies show VIF values smaller than 10 and tolerance rates show above 0.10 , so it can be said that this regression model does not have multicollinearity problem.

\subsubsection{Heteroscedasticity Test}

The following results of Heteroscedasticity test

Table 4. Test Glejser.

\begin{tabular}{|c|c|c|c|c|c|}
\hline \multirow[t]{2}{*}{ Model } & \multicolumn{2}{|c|}{$\begin{array}{l}\text { Unstandardized } \\
\text { Coefficients }\end{array}$} & \multirow{2}{*}{$\begin{array}{l}\text { Stand } \\
\text { ardiz } \\
\text { ed } \\
\text { Coeff } \\
\text { icient } \\
\text { s } \\
\text { Beta }\end{array}$} & \multirow[t]{2}{*}{$\mathrm{t}$} & \multirow[t]{2}{*}{ Sig. } \\
\hline & B & $\begin{array}{l}\text { Std. } \\
\text { Error }\end{array}$ & & & \\
\hline $\begin{array}{l}\text { (Cons } \\
\text { tant) }\end{array}$ & ,153 & ,094 & & 1,628 & ,110 \\
\hline $\mathrm{ROA}$ &,- 100 & 073 &,- 331 & $-1,378$ &, 174 \\
\hline $1 \mathrm{LEV}$ &,- 021 & ,032 &,- 142 &,- 647 &, 521 \\
\hline SZE &,- 003 & ,003 &,- 279 & $-1,336$ & ,188 \\
\hline CAP &,- 022 & ,030 &,- 183 &,- 720 & ,475 \\
\hline INV &,- 001 & ,059 &,- 005 &,- 021 & ,984 \\
\hline
\end{tabular}

a. Dependent Variable: Abs_Res 
Based on the results of SPSS output in the above table, seen from the sig column for profitability, leverage, Size, Capital Intensity and Inventory Intensity> 0,05 so it can not conclude heteroskedastisitas.

\subsubsection{Autocorrelation Test}

The following results are submittedAutocorrelation test.

Table 5. Model Summary ${ }^{\mathrm{b}}$.

\begin{tabular}{llrrrr}
\hline Model & $\mathrm{R}$ & R Square & $\begin{array}{c}\text { Adjusted R } \\
\text { Square }\end{array}$ & $\begin{array}{c}\text { Std. Error of the } \\
\text { Estimate }\end{array}$ & $\begin{array}{c}\text { Durbin- } \\
\text { Watson }\end{array}$ \\
\hline 1 &, $457^{\mathrm{a}}$ &, 209 &, 128 &, 03581 & 2,178 \\
\hline
\end{tabular}

a. Predictors: (Constant), INV, LEV, SZE, ROA, CAP

b. Dependent Variable: ETR

By looking at the autocorrelation test output, it shows that the Durbin Watson (DW) value in the statistical calculation is 2.178. From the Durbin Watson table with the number of samples $(\mathrm{N})$ is 55 , the free variable $(\mathrm{K})$ is 5 . There is a upper limit value $(\mathrm{dU})$ of 1.7681 and the lower limit value $(\mathrm{dL})$ of 1.3743 . In this autocorrelation test analysis with Durbin Watson (dU $(1,7681)<\mathrm{DW}(2,178)<2,2319$ there is no autocorrelation.

\subsubsection{Determination Coefficient Test (R2)}

The following results of Coefficient Determination test.

Table 6. Model Summary .

\begin{tabular}{lccccc}
\hline Model & $\mathrm{R}$ & R Square & $\begin{array}{c}\text { Adjusted R } \\
\text { Square }\end{array}$ & $\begin{array}{c}\text { Std. Error of the } \\
\text { Estimate }\end{array}$ & $\begin{array}{c}\text { Durbin- } \\
\text { Watson }\end{array}$ \\
\hline 1 &, $457^{\mathrm{a}}$ &, 209 &, 128 &, 03581 & 2,178 \\
\hline $\begin{array}{l}\text { a. Predictors: (Constant), INV, LEV, SZE, ROA, CAP } \\
\text { b. Dependent Variable: ETR }\end{array}$
\end{tabular}

Based on the above table, the value of Adjusted R Square (R2) is equal to 0.128 or $(12.8 \%)$. It can be concluded that $12.8 \%$ of the tax avoidance value of food and beverage manufacturing companies is determined by the characteristics of firms proxied by profitability, leverage, size, capital intensity, inventory intensity while the remaining $87.2 \%(100 \%-12.8 \%)$ due to other variables outside the study. 


\subsubsection{Analysis of Model Feasibility Test Result}

The following results of the feasibility test of the Model.

Table 7. ANNOVA.

\begin{tabular}{lllllll}
\hline Model & & $\begin{array}{l}\text { Sum of } \\
\text { Squares }\end{array}$ & df & $\begin{array}{l}\text { Mean } \\
\text { Square }\end{array}$ & F & Sig. \\
\hline \multirow{2}{*}{1} & Regression &, 017 & 5 &, 003 & 2,588 &, $037^{\mathrm{b}}$ \\
& $\begin{array}{l}\text { Residual } \\
\text { Total }\end{array}$ &, 063 & 49 &, 001 & & \\
\hline
\end{tabular}

a. Dependent Variable: ETR

b. Predictors: (Constant), INV, LEV, SZE, ROA, CAP

From the above explanation, the result of $F$ test in this research shows that the conclusion obtained is $\mathrm{Ha}$ accepted, which means that the Company Characteristic proxied by profitability, leverage, size, capital intensity and inventory intensity simultaneously have significant effect on tax avoidance (Tax Avoidance). So it can be concluded the model is worth using.

\subsubsection{Hypothesis Testing Research (Test T)}

Hypothesis testing in this study aims to determine whether or not the influence of independent variables individually to the dependent variable tested at a significant level of 0.05 (Ghozali, 2013)

Table 8. Test $\mathrm{T}$.

\begin{tabular}{|c|c|c|c|c|c|c|c|c|}
\hline & \multirow[t]{2}{*}{ Model } & \multicolumn{2}{|c|}{$\begin{array}{l}\text { Unstandardized } \\
\text { Coefficients }\end{array}$} & \multirow{2}{*}{$\begin{array}{c}\text { Standardized } \\
\text { Coefficients } \\
\text { Beta }\end{array}$} & \multirow[t]{2}{*}{$\mathrm{t}$} & \multirow[t]{2}{*}{ Sig. } & \multicolumn{2}{|c|}{ Collinearity Statistics } \\
\hline & & B & $\begin{array}{l}\text { Std. } \\
\text { Error }\end{array}$ & & & & Tolerance & VIF \\
\hline \multirow{6}{*}{1} & (Constant) & ,561 &, 173 & & 3,234 &, 002 & & \\
\hline & ROA &,- 369 &, 134 &,- 617 & $-2,746$ & ,008 & ,320 & 3,123 \\
\hline & LEV &,- 029 &, 059 &,- 102 &,- 497 & ,621 & ,384 & 2,605 \\
\hline & SZE &,- 006 & ,005 &,- 245 & $-1,255$ &, 215 & ,422 & 2,368 \\
\hline & CAP &,- 136 &, 056 &,- 573 & $-2,413$ & ,020 & 286 & 3,492 \\
\hline & INV &,- 279 & ,109 &,- 578 & $-2,554$ & ,014 & ,315 & 3,172 \\
\hline
\end{tabular}

a. Dependent Variable: ETR

Researchers formulate regression model as follows:

$Y=0,561$ - 0,369(X1) - 0,029(X2)- 0,006(X3) - 0,136(X4) -0,279(X5)ع

As explain:

$\alpha=$ Value of Constant, ie Y if X1, X2, X3, X4, X5 = 0

$\mathrm{X} 1$ - X5 = Regression coefficient of each Independent Variable

$\varepsilon=$ Error (interference factor)

\subsection{Interpretation of Research Results}




\subsubsection{Influence Characteristics of proxy companies Profitability against Tax Avoidance.}

Corporate Characteristics ROA proxy has a negative effect on tax avoidance which means higher profitability level, the lower the tax avoidance level (Tax Avoidance). The high value of ROA cause the company's performance better. The value of profitability will affect the actions taken by the company. Management considers the availability of information from the value of profitability, and considers the implications and implications of actions taken implicitly and explicitly including actions to practice tax avoidance. Errors arising from improper action taking will affect the company's image [19]. Theory of reasoned action explains how firm behavior is influenced by a basic consideration of the desired behavior. Companies with good profitability are assumed not to tax avoidance because the company's image will be bad if the company does the practice. This is in line with the results of research conducted by (Khusniyah Tri Ambarukmi, 2017) which states that profitability has a significant negative effect on tax avoidance [12]. But the results of this study are not in line with the results of research conducted by (Siregar and Widyawati, 2016) which states profitability has no effect on tax avoidance [9].

\subsubsection{Influence Characteristics of leverage proxy companies Against Tax Avoidance.}

Company Characteristics of leverage proxy has no significant effect on Tax Avoidance. Due to the large amount of funding a company can not determine the practice of tax avoidance. This is because the use of debt to the company is to meet the operational needs and investment companies, so the size of the leverage does not affect the avoidance of taxes. The results of this study are in line with the research conducted by (Nurfadilah et al., 2015), namely Leverage has no effect on tax avoidance [2] and (Ngadiman and Puspitasari, 2014) stated that Leverage has no significant effect [20]. However, the results of this study are not in line with research conducted by (Koming Ayu Praditasari and Ery Setiawan, 2017) and (Ariawan and Setiawan, 2017) proving that leverage partially positively affect tax avoidance [15], [8].

\subsubsection{Influence Characteristics of proxy company Size against Tax Avoidance}

Not have a significant effect on Tax avoidance. Companies that belong to large-scale companies will have abundant resources that can be used for specific purposes [14]. The size of the company (Size) shows the stability and ability of the company to conduct its economic activities. Whether large or small, the size of the company, if the company's records and bookkeeping properly and in accordance with company policies and regulations, then no effect on tax evasion. This research is in line with research conducted by (Nurfadilah et al., 2015) Declared that firm size (Size) has no significant effect on tax avoidance (Tax Avoidance) [2]. However, this study is not in line with research conducted (Dharma and Ardiana, 2016) which states that size has a significant effect tax avoidance [3].

\subsubsection{Influence Characteristics of the company's proxy Inventory Intensity against Tax Avoidance}

Characteristics of proxy capital intensity companies have a negative and significant effect on tax evasion. That is, the higher the capital intensity then the tax evasion of companies will be lower. The greater the amount of capital invested the greater the tax avoidance by the company. Rodriguez and Arias (in (Zulaikha, 2014) say that the company's fixed assets allow 
the company to reduce its taxes due to depreciation arising from fixed assets annually [21]. This is because the depreciation expense of this fixed asset will directly reduce the company's profit on which the company's tax calculation is based. The results of this study support the results of (Putri and Launtania, 2016) states that Capital Intensity effect on tax avoidance (Tax Avoidance) [13]. While the results of this study are not in line that is done (Siregar and Widyawati, 2016) which states capital intensity has no positive effect on tax avoidance [9].

\subsubsection{Influence Characteristics of proxy companies Capital Intensity Tax Avoidance (Tax Avoidance)}

Characteristics of INV Company proxies have a negative effect on tax evasion (ETR). In other words, if the inventory intensity of the company increases then it will affect the level of tax evasion by the company. Capital intensity and inventory intensity are the asset mix asset variables that become substitutes for each other. High inventory intensity will increase the company's net profit because the costs contained in the inventory can be efficient. The Company will increase the ending inventory to reduce inventory intensity and increase the costs contained within the company to reduce the company's profit so that its tax burden decreases. The results of this study are in line with the research (Nugroho, Ahmar and Darmansyah, 2016), states that Inventory Intensity affect tax avoidance (Tax Avoidance) [11]. While this research is not in line with (Khusniyah Tri Ambarukmi, 2017)(Putri and Launtania, 2016), states that Inventory Intensity has no effect on tax avoidance (Tax Avoidance) [12],[13].

\section{Conclusions}

Based on data the result described in the previous chapter, it can be concluded that:

1. Characteristics of Profitability proxy companies have a negative effect on tax avoidance.

2. Characteristics of Leverage proxy companies have no effect on tax evasion.

3. Characteristics of proxy companies Size has no effect on tax avoidance.

4. Characteristics of Capital Intensity proxy companies have a negative effect on tax avoidance

5. Characteristics of proxy companies Inventory Intensity negatively affect the avoidance of taxes

\subsection{Managerial Implications}

In research to reduce the tax burden the management can perform various ways such as tax avoidance. This is not in line with the research conducted there are four variables that have no effect, including:

1. For Sub Sector of Food and Beverage Companies Expected to be additional information for the characteristics of the company that there is potential in tax avoidance (Tax Avoidance), Because it will have an impact on the financial sector causingequalities between the budget and other consequences associated with it, such as tariff increase taxes and the state of inflation as well as for the economic sector cause stagnation (stalled) economic growth or rotation wheel economy. 
2. For Investors

Can be a reference in making investment decisions by knowing the detection of companies that do tax avoidance (Tax Avoidance).

3. For Regulators

Can be a reference government in the preparation of regulations on tax avoidance (Tax Avoidance), so that State tax revenue has increased.

\subsection{Limitations of Research}

Limitations of this study are:

1. In this study only tested the characteristics of the company proxied by Profitability, Leverage, Size, Capital Intensity and Inventory Intensity.

2. The observation time period in the study was conducted at 5 years (2012-2016).

3. The sample of research involves only 11 manufacturing companies with the Food and Beverage Industry sector listed on the Indonesia Stock Exchange (BEI).

\subsection{Suggestion}

Based on the conclusions and limitations of the research mentioned above, some suggestions may be given as follows:

1. Further research is expected to conduct research on companies listed on the Indonesia Stock Exchange (BEI) engaged in a broader field and not limited to food and beverage manufacturing.

2. For future researchers who will examine the same thing by considering other factors such as sales growth, audit committee, and others.

3. Further research not only uses the Effective Tax Rate (ETR) as a measurement in the search for tax avoidance, it should be added with other measurements such as Cash Effective Tax Rate (CETR), and the timeframe should be extended to find out the longterm research impact and get a prediction which is more appropriate.

4. The next researcher is expected to use a sample of the company and a longer study period in order to obtain better results.

For firms the object of the study is expected to evaluate the performance of the company, and not to avoid tax evasion, since tax evasion will lead to tax witnesses. And for the government it is expected that the fiscal increase the supervision or monitoring of companies that report their tax obligations and ensure that the company applies the applicable Financial Accounting Standards, so that no companies will avoid taxes.

\section{References}


[1]Www.sp.berisatu.com, "No Title." .

[2]Nurfadilah, H. Mulyati, M. Purnamasari, and H. Niar, "Pengaruh Leverage, Ukuran Perusahaan, dan Kualitas Audit Terhadap Penghindaran Pajak ( Studi Empiris pada Perusahaan Manufaktur yang terdaftar di Bursa Efek Indonesia Tahun 2011-2015 )," Semin. Nas. dan 3rd Call Syariah Pap., no. 2010, pp. 441-449, 2015.

[3]I. M. S. Dharma and P. A. Ardiana, "Pengaruh Leverage, Intensitas Aset Tetap, Ukuran Perusahaan, dan Koneksi Politik Terhadap Tax Avoidance,” E-Jurnal Akunt. Univ. Udayana, vol. 15, no. 1, pp. 584-613, 2016.

[4]T. A. . Surbakti, "Pengaruh Karakteristik Perusahaan Dan Reformasi Perpajakan Terhadap Penghindaran Pajak Di Perusahaan Industri Manufaktur Yang Terdaftar Di Bursa Efek Indonesia Tahun 2008- 2010,” 2012.

[5]S. Mulyani, Darminto, and M. G. W. E. N.P, "Pengaruh Karakteristik Perusahaan, Koneksi Politik dan Reformasi Perpajakan Terhadap Penghindaran Pajak (Studi Pada Perusahaan Manufaktur Yang Terdaftar di Bursa Efek Tahun 2008-2012),” J. Bisnis Manaj. dan Ekon., vol. 2, no. 1, pp. 1-9, 2014.

[6]I. Fahmi, Pengantar Manajemen Keuangan. Bandung: Alfabeta, 2013.

[7]I. A. R. Dewinta and P. E. Setiawan, "Pengaruh Ukuran Perusahaan, Umur Perusahaan, Profitabilitas, Leverage, Dan Pertumbuhan Penjualan Terhadap Tax Avoidance," E-Jurnal Akunt. Univ. Udayana, vol. 14, no. 3, pp. 1584-1613, 2016.

[8]I. M. A. R. Ariawan and P. E. Setiawan, "Pengaruh Dewan Komisaris Independen , Kepemilikan Avoidance,” E-Jurnal Akunt. Univ. Udayana ISSN 2302-8556, vol. 18, pp. 1831-1859, 2017.

[9]R. Siregar and D. Widyawati, "Pengaruh Karakteristik Perusahaan Terhadap Penghindaran Pajak Pada Perusahaan Manufaktur Di Bei,” J. Ilmu Ris. Akunt., vol. 5, no. 2, 2016.

[10]L. P. S. dan Y. J. Christiawan, “Analisa Faktor yang Mempengaruhi Likuiditas Pada Industri Ritel yang Terdaftar Pada Bursa Efek Indonesia Tahun 2007-2012,” Bus. Account. Rev., vol. 3, no. 3, p. 56, 2012.

[11]A. Nugroho, N. Ahmar, and Darmansyah, "Determinan Tax Avoidance Pada Perusahaan Industri Manufaktur Di Bursa Efek Indonesia," VE-Jurnal Akunt. J. GICI, vol. 7, pp. 1-18, 2016.

[12]N. D. Khusniyah Tri Ambarukmi, "Pengaruh Size, Leverage, Profitability, Capital Intensity Ratio, dan Activity Ratio Terhadap Effective Tax Rate,” J. Akunt. Univ. Islam Malang, vol. 06, no. 17, pp. 13-26, 2017.

[13]C. L. Putri and M. F. Launtania, "Pengaruh Capital Intensity Ratio, Inventory Intensity Ratio, Ownership Structure dan Profitability terhadap Effective Tax Rate (Studi pada Perusahaan Manufaktur yang Terdaftar di Bursa Efek Indonesia Tahun 2011-2014),” J. Ilm. Mhs. Ekon. Akunt., vol. 1, no. 1, pp. 101-119, 2016.

[14]I. G. H. dan I. M. S. Darmawan, "Pengaruh Penerapan Corporate Governance, Leverage , Return On Assets, Dan Ukuran Perusahaan Pada Penghindaran Pajak I Gede Hendy Darmawan,” E-Jurnal Akunt. Univ. Udayana, vol. 9, pp. 143-161, 2014.

[15]N. Koming Ayu Praditasari and P. Ery Setiawan, "Pengaruh Good Corporate Governance, Ukuran Perusahaan, Leverage Dan Profitabilitas Pada Tax Avoidance," E-Jurnal Akunt. Univ. Udayana, vol. 19, pp. 1229-1258, 2017.

[16]Rita andini supriyanto, kharis raharjo, "Journal Of Management, Volume 2 No.2 Maret 2016," Accounting, vol. 2, no. 2, pp. 1-19, 2016.

[17]P. Widhianningrum, "Perataan Laba dan Variabel - Variabel yang Mempengaruhinya (Studi Empiris Perusahaan Manufaktur yang Terdaftar di BEJ),” J. Akunt. dan Pendidik., vol. 1, no. 1, pp. 24-33, 2012. 
[18]Christina Widhya Utami, Manajemen Ritel. Jakarta: Salemba Empat, 2013.

[19]N. K. Y. Utari and N. L. Supadmi, "Pengaruh Corporate Governance, Profitabilitas Dan Koneksi Politik Pada Tax Avoidance,” E-Jurnal Akunt. Univ. Udayana, vol. 18, pp. 22022230, 2017.

[20]Ngadiman and C. Puspitasari, "Pengaruh Leverage, Kepemilikan Institusional, dan Ukuran Perusahaan Terhadap Penghindaran Pajak (Tax Avoidance) Pada Perusahaan Sektor Manufaktur Yang Terdaftar Di Bursa Efek Indonesia 2010-2012,” J. Akunt., vol. 18, no. 03, pp. 408-421, 2014.

[21]Danis ardiansyah dan Zulaikha, "Pengaruh Size, Leverage, Profitability, Capital Intensity Ratio Dan Komisaris Independen Terhadap Effective Tax Rate (Etr)," Diponegoro J. Account., vol. 3, pp. 1-9, 2014. 